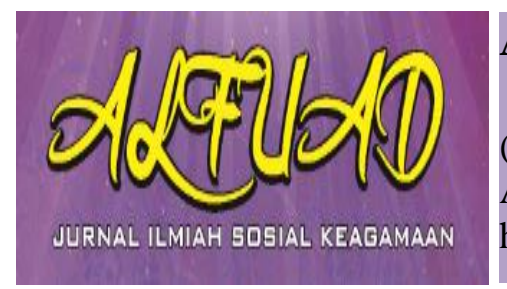

ALFUAD JOURNAL, 3 (2), 2019, (15-24)

(Print ISSN 2614-4786)

Available Online at

http://ecampus.iainbatusangkar.ac.id/ojs/index.php/alfuad

\title{
PEACEFUL CAMPAIGN IN ELECTION AL-HUJURAT VERSE 11 PERSPECTIVE
}

\section{Doli Witro}

Institut Agama Islam Negeri (IAIN) Kerinci Email: doliwitro01@gmail.com

\begin{abstract}
Democracy is a government of the people, by the people and for the people. The popularity of the democratic system is arguably at its peak. This is proven by the many uses of the democratic system in modern countries in the world. Indonesia as a country that runs a democratic system does not give authority to the authorities to monopolize votes in an election. Because security and freedom for every citizen, free to choose as a representation of the sovereignty of the people. But on the side that democracy often happens is seen as freedom so that there are some elements mixing elements in democracy that actually damage democracy itself. Call it when campaigning for a candidate to hate speech, insult, and berate other candidates so that damage the good name in the eyes of the community. As reported in Detik.com in 2016, the National Police stated that there were 2,018 cases of hate speech that occurred. Then it increased by $44.99 \%$ in 2017 to 3,325 cases. Furthermore, in 2018 reported in January 2019 there were 3,884 cases of hate speech that occurred. This proves that in campaigning the candidates cannot be said to campaign peacefully, fairly and competitively. Whereas Allah s.w.t. It has been said in Surah alHujurat verse 11. Based on the description above the writer is interested in discussing and studying more about the campaign in the Elections in Indonesia and campaigning peacefully perspective of Surah al-Hujurat verse 11. This is important to discuss given the rampant hate speech cases that conducted by candidates in campaigning. This study aims to contribute knowledge to the candidates so that in campaigning, they do not utter hate speech, insult, and berate other candidates.
\end{abstract}

Keywords: Election, Campaign, Surat Alhujurat Verse 11

\section{INTRODUCTION}

You can but election without democracy, but you can without election. The fragment of the sentence shows how important the General Election is for the State implementing a democratic system (Simanjuntak, 2017: 306). Abraham Lincoln stated that democracy is the government of the people, by the people and for the people (Mahfud, 1999: 23). The popularity of the democratic system is arguably at its peak. This is proven by the many uses of the democratic system in modern countries in the world. Its use is none other than the democratic system prioritizing and always prioritizing the equality of rights and positions owned by every citizen in the government (Sarbaini, 2015: 106). 
Indonesia as a country that runs a democratic system does not give authority to the authorities to monopolize votes in an election. Because in the archipelago (read: Indonesia) it has stated security and freedom for every citizen, free to choose as a representation of people's sovereignty. That security and freedom as mentioned in article 27 paragraph (1) of the 1945 Constitution. On that basis, in every Election held in Indonesia, the government is obliged to provide security and freedom to citizens to choose according to their respective conscience (Arifuddin, 2017: 394).

Therefore, the implementation of the General Election has received serious attention from various groups. This is due to the fact that many countries consider the Election as an ideal system as a peaceful and orderly power transfer mechanism within a country. The assumption that is built temporarily is that if the election is carried out properly, then democracy can run well too (Simamora, 2014: 2). In spite of that, democracy is often seen as a freedom so that there are some elements mixing elements in democracy that actually damage democracy itself. Call it when campaigning for a Legislative Candidate to utter hate speech, insulting, and berating other candidates so as to damage the good name in the eyes of the community.

For example, Ahmad Dhani who uttered hate speech against Basuki Tjahaja Purnama (aka Ahok) in January 2019. As is known at that time Dhani was a candidate from a party. Therefore, due to his actions Dhani stays in prison for 1.5 years (Tempo.co, 2019). This case is one of many cases of hate speech. As reported in Detik.com in 2016, the National Police stated that there were 2,018 cases of hate speech that occurred. Then it increased by $44.99 \%$ in 2017 to 3,325 cases (Detik.com, 2017). Furthermore, in 2018 reported in January 2019 there were 3,884 cases of hate speech that occurred (Okezone.com, 2019). This proves that in campaigning the candidates cannot be said to campaign peacefully, fairly and competitively. Whereas Allah s.w.t. It has been said in Surah al-Hujurat verse 11:

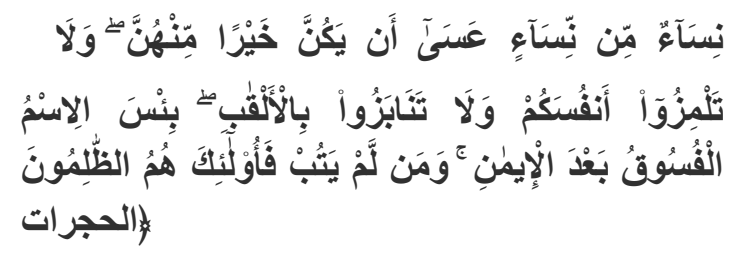

Means:

O ye who believe! Let not a folk deride a folk who may be better than they (are), not let women (deride) women who may be better 
than they are; neither defame one another. (Q.S. 49 : 11)

In addition to the above verse the Prophet Muhammad also confirmed in a hadith narrated by Imam Muslim which means: "And whoever makes (pioneers) a bad deed in Islam, for him the sin and (coupled with) the sins of those who practice it afterwards, without reducing their sins in the slightest". (H.R. Muslim No. 1017)

Based on the description above, the writer is interested in discussing and studying more about the campaign in the General Elections in Indonesia and peacefully campaigning on the perspective of Surat al-Hujurat verse 11. This is important to discuss given the rampant cases of hate speech by candidates in campaigning. This study aims to contribute knowledge to the candidates so that in campaigning, they do not utter hate speech, insult, and berate other candidates.

\section{RESULT AND DISCUSSION}

\section{Campaign in Indonesian Election}

The word Election universally comes from English namely general election. In the Black's Law Dictionary the definition of election is the process of selecting a person to occupy an office (usually a public office), membership, award, or other title or status. While general election in the same reference is interpreted as an election that occurs at a regular interval of time or which means that elections are held on a structured and routine time scale (Bisyariyadi, 2012: 14). In article 1 paragraph (1) of Law Number 22 Year 2007 concerning the Implementation of General Elections it is stated that:

General Election, hereinafter referred to as Election, is a means of implementing popular sovereignty which is held directly publicly, freely, confidentially, honestly and fairly in the Unitary State of the Republic of Indonesia based on Pancasila and the 1945 Constitution of the Republic of Indonesia.

Subakti (1992: 181) stated that the election was a selection mechanism so that an envoy was trusted to the party or someone. In organizing it, at least the Election has 3 objectives: 1) As a mechanism that selects a leader as an alternative to general policy; 2) As a transfer of community interests through people or a party they trust so that their welfare can be guaranteed; 3) As a means of mobilizing, mobilizing and channeling people's support for the country as evidenced by the political participation shown by the community (Prihatmoko, 2003: 19). 
Elections are a means of carrying out democracy. It can even be said that there is no democracy without elections. Even so, the success of the general election is not the ultimate goal of a democracy. Because the election is only as a means to produce the best leaders who are ready to lead the center (read: parliament) and the region. The purpose of implementing the democratic system is none other than what is stated in the 1945 Constitution which is to advance the general welfare and intellectual life of the nation.

Furthermore, the success of an election can not stand alone, but is determined by the maturity of political actors "politicians and parties", the political culture in society and the readiness of the administration of election organizers. All that alone is not enough, of course there are obstacles and obstacles such as heterogeneous (diverse) societies that have low political awareness and participation, poor population registration, hate speech that is often done by candidates, all of which can cause the failure of an election (Khasanah, 2017: 367-368).

Therefore, in a democratic election plays a significant role. In achieving the success of the General Election, collaboration between various parties participating in a political contestation is needed. Whether it's the community, Caleh (party), and government. This is none other than to achieve a successful election that is not easy. Now, to achieve a successful election, we need a process of carrying out elections with integrity.

Elections with integrity, namely in the implementation of elections, must meet indicators such as honesty, fairness, freedom, generality, and secrecy to produce people's representatives in a government. The representatives must understand that he is among the 560 people trusted by the Indonesian community of 268 million people fighting for their aspirations in parliament. Likewise at the provincial, district / city, and so on (Saragih and Ginting, 2017: 356).

Therefore the candidates are competing to find community sympathizers in order to win a political contestation. They campaigned to get these investigators. Campaigning is an effective way. Campaign is an action or activity carried out by a candidate or political party in competing for a position in parliament by gaining the support of a mass of voters in an election (Ashsubli, 2016: 14). 
In Islam, political issues are known as fiqh siyasah. Indeed, a standard definition of campaign has not yet been found. But there are some behavioral elements that indicate a campaign such as offering to be a leader and inviting the public to choose and support him as a leader. That is because the term campaign emerged in contemporary times. Although it does not exist in Islam, the implicit mention of the campaign is alQur'an as contained in the verse Yusuf verse 55:

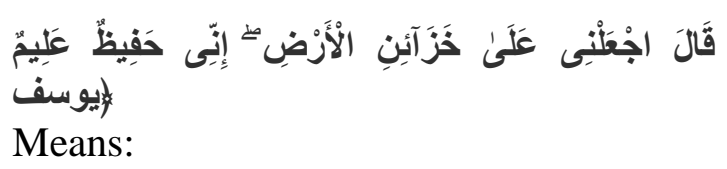

He said: "Set me over the storehouses of the land. Lo! I am a skilled custodian". (Q.S. 12: 55)

Al-Allamah al-Alusi explained that the above verse is an argument which allows a person to nominate and offer himself when he is not known by the local community (Huwaydi, 1996: 236). Al-Qurtubi stated that the verse shows that it is permissible for someone to offer himself to a certain position if he is indeed competent. Al-Qurtubi further explained in the verse that the Prophet Yusuf a.s offered himself to be an Egyptian surgeon in none other than to uphold justice and restore the rights of the poor (as-Suwaidan, 2005: 30).
In addition to the above verse, Allah s.w. also confirmed in Surah alQashash verse 26:

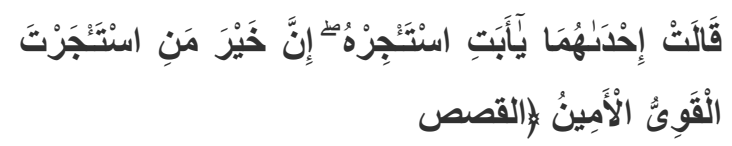

Means:

One of the two women said: O my father! Hire him! For the best (man) that thou canst hire in the strong, the trustworthy. (Q. S. 28: 26)

If there is a term "there is no democracy if there are no elections", then it is not excessive if it says "there is no election without a campaign". In fiqh siyasa, the term Election is known as intikhabah al-amanah. Intikhabah is the name of muannassalim which comes from the word intikhaba, yantakhibu which means to choose. Departing from this understanding, the campaign can further be said to be an activity which contains a candidate introducing himself, explaining the purpose of his leadership, and so forth. So that the public knows who among the candidates are worthy of occupying a government seat and also knows who these candidates are and what their vision and mission is (Cangara, 2011: 299). As for the parties that carry out campaign activities are teams that have been formed by parties or formed by candidates, or candidates themselves who immediately jumped into campaigning. 


\section{Peaceful Campaign Al-Hujurat Verse 11 Perspective}

To see an election that has implemented fair and free competition can be seen from the process taken / passed by the candidates in getting votes (supporters). As the election must be free from intimidation, violence, money politics and also carried out in a manner authorized by law. On the other hand, the campaign carried out by the Legislative Candidates may also not denigrate the nation, region, race, gender and religion. But it must go through fair, safe and free competition in the conduct of an election as guaranteed in government regulations and election legislation (Manullang, 2017: 381). One example is contained in Law Number 10 of 2016 article 182 which reads:

Every person intentionally commits an illegal act by using violence, threats of violence, and obstructing someone who will exercise his right to vote, shall be sentenced to a minimum of 24 (twenty four) months and a maximum of 72 (seventy two) months and a fine of at least Rp. 24,000,000 (twenty four million rupiah) and a maximum of Rp. 72,000,000 (seventy two million rupiah).

Although there are many regulations governing elections, the practice of implementing them in practice still poses various problems. So that it seems the election has not shown free and fair competition. This can be seen from the many acts of hate speech, intimidation and discrimination to other candidates carried out by a campaign team formed by the party, sympathizers and volunteers from one of the candidates (Manullang, 2017: 381). Even though Allah has explained that one must not utter hate speech, insult, make fun of, and berate others, as contained in Surah alHujurat verse 11:

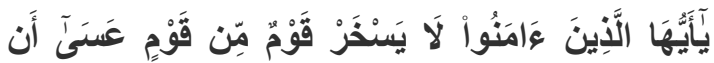

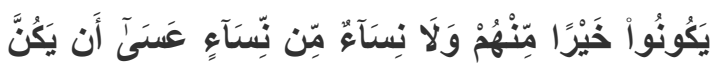

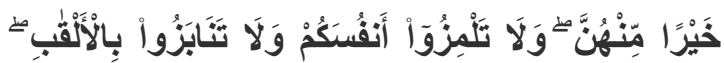

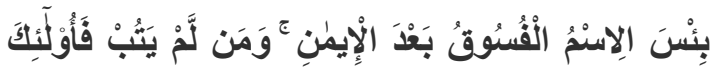

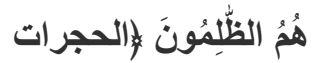

Means:

O ye who believe! Let not a folk deride a folk who may be better than they (are), not let women (deride) women who may be better than they are; neither defame one another, nor insult one another by nicknames. Bad is the name of lewdness after faith. And whoso turneth not in repentance, such are evil-doers. (Q. S. 49: 11)

Usamah ar-Rifa'I (2008: 517) in his interpretation of tafsirul wajiz stated that layaskhar means not to make fun. The same meaning explained by Quraish Shihab (2009: 603-605) in its interpretation of tafsir al-misbah which 
states the word yaskhar in the above verse means to mock that is to mention the shortcomings of others with the aim to embarrass them, both by deeds and speech. Then the word qaum is meaningful to a group of people. The word qaum here shows the prohibition of men only, although in the word qaum it embraces women as well. But in this verse the woman has been mentioned with a special word namely nisa'. The word nisa' is used here because mocking, mocking, and mocking are more common among women than men. Then talmizu comes from the word al-lamz which means ridicule. Some scholars disagree about this problem, some say ridicule is done directly and some understand indirectly. "Then the word tanabazu is taken from the word an-Nabz, which is with a bad title. At-tanabuz means mutual, that is a reply from someone being ridiculed to someone who mocked".

Jalaluddin Muhammad ibn Ahmad and Jalaluddin Abdirrahman ibn Abu Bakr as-Suyuthi (2015: 476) in their interpretation of tafsir jalalain states when viewed from the cause of the decline in verse. This verse came down because of the Tamin tribe who despised the poor of the friends namely Ammar bin Yasir. This verse also shows that people who have a position and wealth often feel themselves better than the poor. Strengths and wealth that a person does not necessarily make themselves better than others. Because who is better in the sight of Allah is someone who is God fearing Him. Likewise with the Legislative Candidates, the popularity and wealth they own does not become a legitimacy for him to freely denigrate, insult, revile the other candidates. So someone should be afraid of ridiculing what is said to others as taught "Abdullah Ibn Mas'ud said: bala 'sometimes arises because someone does not keep his words, so if he deflates someone with a call for ajing, then he should be afraid of being made God has the nature like a dog" (as-Showi, t.t.: 11).

Allah s.w.t. reinforce the prohibition of making fun of the continuation of the above verse namely surah al-Hujurat verse 12:

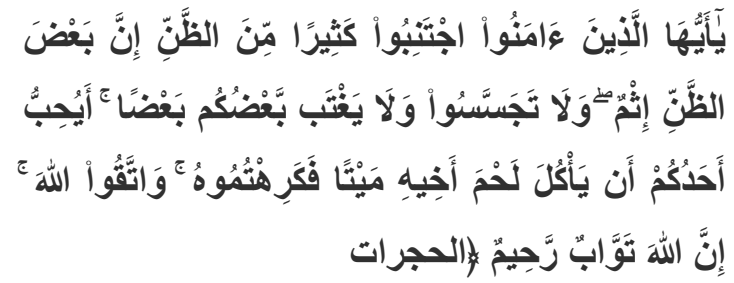

Means:

O ye who believe! Shun much suspicion; for lo! some suspicion is a crime. And spy not, neither backbite one another. Would one of you love to eat the flesh of his dead brother? Ye abhor that (so abhor 
the other)! And keep your duty (to Allah). Lo! Allah is Relenting, Merciful. (Q. S. 49: 12)

Jalaluddin Muhammad and Jalaluddin Abdirrahman (2015: 477) stated that ijtanibuu kasiiran means stay away from most. Meanwhile according to the Quraish shihab (2009: 609) the word ijtanibu is taken from the word janb which means side. This word means to put something aside from the reach of the hand. More simply means stay away. The word ijtanibu also contains the emphasis to stay away from something seriously and also seriously in avoiding prejudice. Then the word katsir means a lot does not mean a lot. Like many translators by other translators, one of them is in the interpretation of tafsir jalalain above.

Then the word tajassasu comes from the word jassa, which is an attempt to find out the hidden from someone who is usually called a spy (jasus). In a hadith also mentioned as narrated by Imam Malik of Abu Hurairah that the Prophet s.a.w said means: stay away from prejudice, because that prejudice is the most lying words. Don't research other people's secrets, steal your ears, compete in bad ways, hate each other, hate each other, and turn away from each other. Be you servants of God, brothers and sisters. (H.R. Malik)
Imam al-Ghazali understands this prohibition in the sense of someone who is not happy to let others keep anything from him. In essence, one may hide something from others. So someone always wants to try to reveal someone else's secret. This kind of thing is forbidden in Islam, let alone intended to ridicule and insult others in public (Syofrianisda, 2018: 2).

Furthermore, in verse al-Hujurat verse 12 there is also the word yaghtab which comes from the word ghibah. The word ghibah comes from the word ghaib which means not present. Ghibah is someone who calls the shortcomings of others who are not pleased with the public (Shihab, 2009: 613). Now, in campaigning every candidate does not have to mention the shortcomings of other candidates in front of the public, even though he knows the shortcomings and disgrace that other candidates have. Because every human being has advantages and disadvantages.

Then in the above verse Allah s.w.t. provide a parable for people who like to mock like eating the meat of someone who has died (read: carcass). As contained in the fragment of the verse an ya'kula lahma ahihi which means to eat the flesh of his brother, maytan means 
something that is dead -reads tasydid and takhfif- which means something that is no longer appropriate to eat (Muhammad and Abdirrahman, 2015: 477).

From the verses in this it can be understood that let alone eating carcasses alone makes people feel disgusted. So, every candidate must not disparage the other candidates in campaigning because talking to other people is like eating the meat of someone who has died. In campaigning a candidate must speak using polite language that does not vilify and offend others. Because the ability to speak is a blessing from God which is very high, even priceless. Moreover, talking is the main communication tool used by someone in their lives (Jauhari, 2013: 29.). In speaking, one must have a clear topic / theme so that it does not wander everywhere, so that it is easy to understand and so that it does not cause negative things such as calamity, slander, and so forth.

\section{CONCLUSION}

Based on the description above it can be understood that a peaceful campaign is a campaign that does not carry out expressions of hatred, berate, and insult other candidates. So the candidates can campaign fair and competitive. Because this has been regulated in Islam, one of them is in Surat al-Hujurat verse 11 . With the peaceful implemeFntation of the campaign, it is expected to produce an election with integrity, which in its implementation fulfills indicators such as honesty, fairness, freedom, generality, and secrecy to produce representatives. people's representatives in a government. Moreover, from elections with integrity it is expected to produce a good democratic system.

\section{REFERENCES}

Ahmad, A., at al. Tafsir as-Showi Syarah Tafsir Jalalain, Juz 4. Surabaya: Dar Ulum.

Arifudin. (2017). Pemilihan Kepala Daerah Sebagai Wujud Implementasi Kedaulatan Rakyat. Jurnal Bawaslu, 3 (3).

Ashsubli, M. (2016). Perspektif Hukum Islam terhadap Pencalonan Diri dan Kampanye untuk Jabatan Politik. Jurnal Ilmu Syari'ah, 15 (1).

Bisyariyadi et. al. (2012). Komparasi Mekanisme Penyelesaian Sengketa Pemilu di Beberapa Negara Penganut Paham Demokrasi Konstitusional. Jurnal Konstitusi, 9 (3).

Cangara, H. (2011). Komunikasi Politik, Konsep, Teori dan Strategi. Jakarta: Rajawali Press.

Departemen Agama RI. (2010). Alquran dan Terjemahnya. Bandung: Syaamil Qur'an. 
Detiknews, Selama 2017 Polri Tangani 3.325 Kasus Ujaran Kebencian, (Online), (http://news.detik.com/, diakses pada 15 November 2019).

Huwaydi, F. (1996). Demokrasi, Opisisi, dan Masyakat Madani, terjemah M. Abdul Ghofar. Badung: Mizan.

Jauhari, M. I. (2013). Adap Sopan Santun. Sumenep: Mutiara Press.

Khasanah, K. (2017). Evaluasi Pemungutan Suara di TPS Menuju Pilkada DKI Jakarta Berintegritas. Jurnal Bawaslu, 3 (3).

Mahfud MD, M. (1999). Pergulatan Politik dan Hukum. Yogyakarta: Gama Media.

Manullang, E. (2017). Parameter Pemilu Demokratik dalam Pilkada DKI Jakarta 2017. Jurnal Bawaslu, 3 (3).

Muhammad, J., \& Abdirrahman, J. (2015). Tafsir Jalalain. terjemah Najib Junaidi. Surabaya: PT. Elba Fitrah Mandiri Sejahtera.

Okenews, Berapa Jumlah Hoaks dan Kebencian dari 2017-2018, Berikut Datanya, (Online), (http;//nasional.okezone.com/, diakses pada 15 November 2019).

Prihatmoko. (2003). Pemilihan Kepada Daerah Langsung. Yogyakarta: Pustaka Pelajar.

Saragih, A., \& Ginting, B. C. (2017). Proyeksi Mewujudkan Pemilu Berintegritas Lewat Netralitas Aparatur Sipil Negara di Pilkada Serentak 2018. Jurnal Bawaslu, 3 (3).

Sarbaini. (2015). Demokratisasi dan Kebebasan Memilih Warga Negara dalam Pemilihan Umum. Jurnal Inovatif, 8 (1).

Shihab, Quraish. (2009). Tafsir alMisbah: Pesan, Kesan, dan Keserasian Alquran, Volume 12. Jakarta: Gema Insani.
Simamora, J. (2014). Menyonsong Rezim Pemilu Serentak. Jurnal Rechtsvinding, 3 (1).

Simanjuntak, N. Y. (2017). Pemantauan dalam Proses Penyelenggaraan Pemilu. Jurnal Bawaslu, 3 (3).

Subakti, R. (1992). Memahami Ilmu Politik, Jakarta: PT. Grasindo.

Syofrianisda. (2018). Pendidikan Ahlak dalam Alquran (Studi Kritis terhadap surat al-Hujurat ayat 1113 dalam Kitab Tafsir al-Misbah Karangan Quraish Shihab). Hikmah: Jurnal Pendidikan Islam, 7 (2). 2.

Tempo.co, Ahmad Dhani Divonis 1,5 Tahum Penjara Atas Kasus Ujaran Kebencian, (Online), (http://metro.tempo.co/read/127152 $8 /$, diakses pada 15 November 2019).

Thariq, A. (2005). Melahirkan Pemimpin Masa Depan. terjemah Faishal Umar. Jakarta: Gema Insani.

Undang-undang Nomor 10 tahun 2016 pasal 182.

Undang-undang Nomor 22 Tahun 2007 tentang Penyelenggaraan Pemilihan Umum.

Usamah, A. (2008). Tasirul Wajiz. Depok: Gema Insani. 